\title{
Histomorphometry of Preterm and Term Human Placentas
}

\author{
Histomorfometría de Placentas de Pretérmino y Término
}

\author{
M. Tariq Zaidi"; Mohd Arshad"; S. M. Vasenwala**; Nafis A. Faruqi*; Aijaz A. Khan* \& Sumbul Khan***
}

ZAIDI, M. T.; ARSHAD, M.; VASENWALA, S. M.; FARUQI, N. A.; KHAN, A. A. \& KHAN, S. Histomorphometry of preterm and term human placentas. Int. J. Morphol., 31(2):409-413, 2013.

SUMMARY: The intra-uterine existence of foetus is dependent on placenta, a major organ of nutrition and homeostasis.The present study was carried out to compare morphometric and histological changes in preterm and term human placentas. Eighty placentas collected from Department of Obstetrics and Gynecology, JNMCH, AMU, Aligarh, were divided into group first of preterm placentas up to 36 weeks ( $n=30)$ and second group of full term placentas i.e. 37 to 40 weeks $(n=50)$ respectively. The samples were fixed in $10 \%$ formol-saline solution. The gross morphological variables of placentas were studied. There was a significant increase in the placental weight, decidual area and umbilical cord diameter of term placenta as compared to that of the preterm ones. From each placenta whole thickness tissue blocks were taken and processed for paraffin sectioning. Five $\mu$-thick sections were stained with Haematoxylin-eosin and Van Gieson stains and processed for light microscopy. A total of 200 villi were studied in each sample under high power field and occurrence of different features was expressed as percentages for each parameter. The appearance of microvilli and syncytial bud on the syncytium were almost absent in the villi of term placentas. It was concluded that with increasing gestational age there was a gradual increase in the number of capillaries in villi from preterm to term placenta.There was a significant increase in syncytial knot count, fibrinoid necrosis, vasculosyncytial membrane and decrease in the percentage of villi showing cytotrophoblastic cells and number of Hofbauer cells in term group as compared to preterm group.

KEY WORDS. Placenta; Syncytial knot; Microvilli; Hofbauer cells; Syncytial bud.

\section{INTRODUCTION}

The placenta is a vital organ for intra-uterine existence of the foetus. The quality and quantity of maternal blood delivered to the intervillous spaces of the placenta determine the development of foetus. Several studies have shown structural alteration in the placenta throughout the normal pregnancy. In order to understand the role of the placenta in foetal growth, one has to know placental changes in relation to gestation. Variations have been found in the placental weight and foetoplacental weight ratios at different gestational ages. This variation depends upon the methods used in handling the placentas (Adair \& Thelander, 1925). In normal preterm and term infants, there is a direct relation between birth weight and weight of the placenta (Adair \& Thelander). Relations between birth weight and placental area and placental volume have also been described (Dow \& Torpin, 1939). Enders \& King (1970) observed the presence of syncytiotrophoblasts and cytotrophoblasts in the villi and absence of basement membrane of the capillaries in early human placentas. Microvilli on the syncytium were also noted (Ursula,1964). The present study is an attempt to find and compare multiple parameters related to gross and histological features and their functional significance in preterm and term human placentas.

\section{MATERIAL AND METHOD}

Eighty placentas were collected from Department of Obstetrics and Gynecology, JNMCH, AMU, Aligarh. These placentas were divided into two groups. First group contained 30 preterm placentas i,e up to 36 weeks of intrauterine life while second group consisted of 50 full term placentas of 37 to 40 weeks of intrauterine life. Placentas of each group were kept in separate container filled with $10 \%$ formal-saline solution. The gross morphological variables of placentas i.e.,

\footnotetext{
* Departament of Anatomy JNMC, AMU, Aligarh, India.

** Departament of Pathology, JNMC, AMU, Aligarh, India.

**** Family Hospital, Aligarh, India.
} 
decidual area, thickness, density, and umbilical cord diameter were noted. From each placenta whole thickness tissue blocks were preserved and processed for paraffin sectioning. Five micron thick sections were stained with Haematoxylineosin and Van Gieson stains. Syncitial knots, cytotrophblastic cells vasculosyncytial membrane, fibrinoid necrosis, microvilli and Hofbauer cells were counted under light microscope in 200 villi for each sample. Data from both gross and microscopic observations were analysed statistically by using Student's T test.

\section{MATERIAL AND METHOD}

The mean placental weight of preterm and term placentas were $352.77 \mathrm{gm}$ and $513.16 \mathrm{gm}$ respectively whereas the mean value of the decidual area found to be $240.10 \mathrm{sq} \mathrm{cm}$ in preterm placenta and $295.768 \mathrm{sq} \mathrm{cm}$ in full term placenta. Increment in both the parameters were statistically significant (Table I).

The mean thickness in preterm placenta was observed to be $1.612 \mathrm{~cm}$ while the same in full term placenta increased to $2.1 \mathrm{~cm}$. but this increase was statistically insignificant.
Density of $0.9974 \mathrm{~kg} \mathrm{~m}-3$ was observed in preterm placenta whereas $0.994 \mathrm{~kg} \mathrm{~m}-3$ was observed in full term placenta. The variation thus observed was also insignificant statistically (Table I). On the other hand the increase in the cord diameter from $9.0376 \mathrm{~mm}$ in preterm placenta to 10.70 $\mathrm{mm}$ in term placenta was statistically significant.

The mean syncytial knot count per 200 villi in placentas of preterm and term groups were 11.8 and 25.83 respectively. The mean value of cytotrophoblastic cells were decreased from 14.16 in preterm group to 1.61 in term group. The mean count of vasculosyncytial membrane in preterm placenta was observed as 1.0 while there was an increased to 22.5 in full term placenta. An average of 1.6 fibrinoid necrosis was observed in placentas of preterm group whereas 4 fibrinoid necrosis in the full term placentas. Interestingly all the aforementioned variations were found to be statistically significant (Table II).

The mean number of microvilli in preterm placenta was observed as 10.0 while these were nil in full term group. Mean value Hofbauer cells in preterm and term placentas were found to decrease from 11.83 to 2.0.The reduction of both aforementioned parameters were statistically significant (Table II).

Table I. Gross features of preterm and term placentas.

\begin{tabular}{lccc}
\hline \multicolumn{1}{c}{ Gross features } & $\begin{array}{c}\text { Pre-term placentas } \\
\text { Mean } \pm \text { SD }\end{array}$ & $\begin{array}{c}\text { Term placentas } \\
\text { Me an士 SD }\end{array}$ & Significance \\
\hline Placental weight $(\mathrm{gm})$ & $352.77 \pm 58.43$ & $513.16 \pm 38.04$ & Significant* \\
Decidual area $\left(\mathrm{cm}^{2}\right)$ & $240.10 \pm 44.503$ & $295.768 \pm 47.11$ & Significant* \\
Thickness $(\mathrm{cm})$ & $1.612 \pm .031$ & $2.19 \pm 0.38$ & Insignificant \\
Density $\left(\mathrm{kg} \mathrm{m}^{3}\right)$ & $0.9974 \pm .0334$ & $0.994 \pm 0.0069$ & Insignificant \\
Umbilical cord-diameter $(\mathrm{mm})$ & $9.0376 \pm 1.591$ & $10.70 \pm 0.333$ & Significant* \\
\hline *P Value $<0.01$ & & &
\end{tabular}

Table II. Histological features of preterm and term placenta.

\begin{tabular}{lccc}
\hline $\begin{array}{l}\text { Histological features } \\
\text { (per 200 villi) }\end{array}$ & $\begin{array}{c}\text { Preterm placentas } \\
\text { Mean士 SD }\end{array}$ & Term placentas & Significance \\
\hline Syncytial knots & $11.8 \pm 4.16$ & $25.83 \pm 2.58$ & Significant* \\
Cytotrophoblastic cells & $14.16 \pm 2.62$ & $1.61 \pm 1.69$ & Significant* \\
Vasculosyncytial membranes & $1 \pm 1.22$ & $22.5 \pm 5.14$ & Significant* \\
Fibrinoid necrosis & $1.66 \pm 1.5$ & $4 \pm 1.4$ & Significant* \\
Microvilli & $10 \pm 5.49$ & 0 & Significant* \\
Hofbauer cells & $11.83 \pm 4.13$ & $2 \pm 0.63$ & Significant* \\
\hline
\end{tabular}

P Value $<0.01$ 


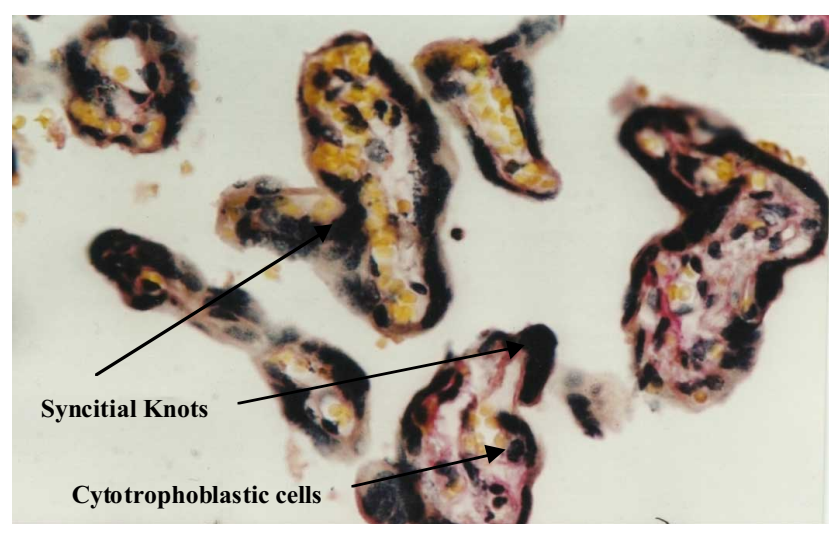

Fig. 1. Chorionic villi of term placenta showing syncitial knots and few cytotrophoblastic cells. V.G stain. X 400.

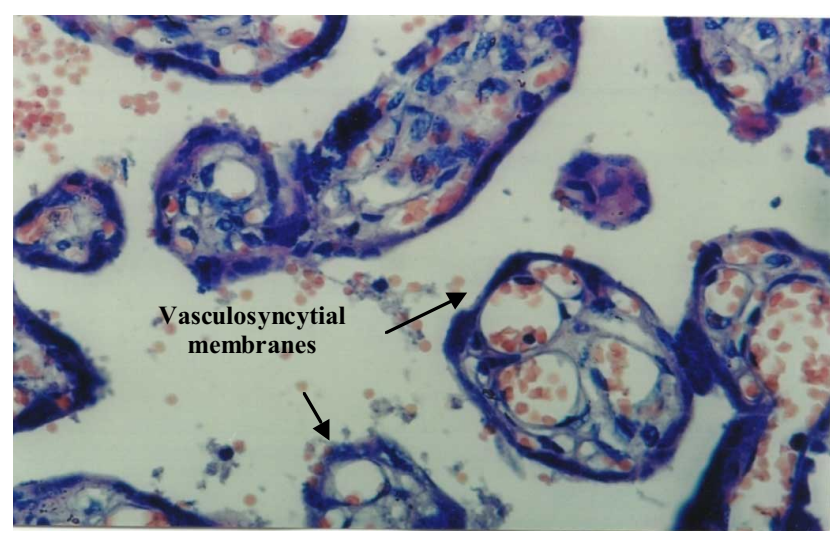

Fig. 2. Chorionic villi of term placenta showing numerous vasculosyncytial membranes. H \& E stain X 400.

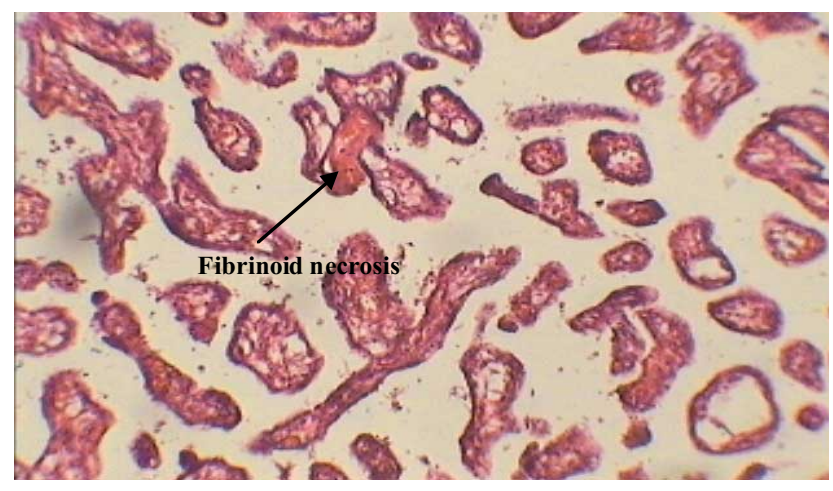

Fig. 3. Chorionic villi showing fibrinoid necrosis in preterm placenta. H \& E stain X 100.

\section{DISCUSSION}

A higher value in the placental weight was observed in full term group compared to preterm one in our study. This was in conformity with the finding of Younoszai \& Haworth (1969). Thompson et al. (1969) were of the view that placental weight varies considerably depending on the

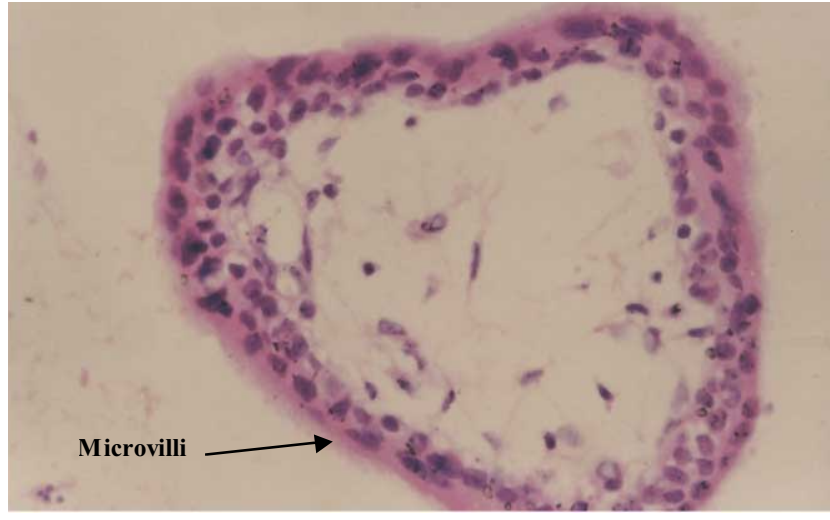

Fig. 4. Chorionic villus of early placenta (6 weeks) showing of microvilli on the periphery and Hofbauer cells. H\& E stain X400.

technique of preparation of the placenta. Although mean percentage of the decidual area were found to increase significantly in our studies, Younoszai \& Haworth found the change as insignificant. Grannum \& Hobbins (1983) reported that placental thickness increased linearly until 36 weeks of pregnancy after which there was a gradual decrease. Koslowski (1980) and Tiwari et al., (1997) also reported similar findings. In our observation change in thickness between preterm and term placentas was insignificant .Insignificant change in mean of density of preterm and term placentas in present study was in conformity with the finding of Younoszai \& Haworth.

Significant increase in umbilical cord diameter in term placenta in our study has parallel study except one reported by Lyndon et al., (1987) who measured diameter of umbilical cord of term placentas in transverse sections and studied its diameter and found it to be $1-2 \mathrm{~cm}$, a value very high. This might be due to late foetal placentas used by latter.

Our observations on syncytial knots were in conformity with the findings of Mirchandani et al.,(1979). According to Jones \& Fox (1977), syncytial knots seem to be a sequestration phenomenon, for the nuclei forming the knots show morphological features suggestive of aging. Mean value of cytotrophoblastic cells in our findings was significantly decreased, the result very much in accordance with the previous studies conducted by Schroder (1930), Hormann (1948) and Clavero (1962). They stated that villous cytotrophoblastic cells, which were so prominent in the early stages of gestation, progressively disappeared as pregnancy advanced and were absent from the mature villi.

Significant increase in vasculosyncytial membrane in preterm placenta in our observation was supported by Fox (1967), who found that $99 \%$ of term placentas from uncomplicated pregnancies had vasculo-syncytial 
membranes on more than $5 \%$ of their villi. He further emphasized that any placenta with an incidence less than afore-mentioned incidence can be considered as being deficient. Fox \& Agrofojo-Blanco (1974) observed localized loss of microvilli over the surface of vasculo-syncytial membranes under electron microscope and concluded that these focally differentiated areas of syncytiotrophoblast are specifically concerned with materno-fetal transfer. A lack of vasculo-syncytial membrane from terminal villi of the placenta represented failure of trophoblastic differentiation and was associated with high incidence of intra-uterine fetal hypoxia. In our observation significant increase in fibrinoid necrosis was found in placentas of full term group. In a parallel study the incidence of fibrinoid necrosis in placentas from uncomplicated term pregnancies was less than 3 per 200 villi (Fox, 1969), a report very close to ours.

Significantly deficient microvilli in term placenta in our study was similar to one reported by Fox \& Agrofojo-
Blanco, who considered this of great functional significance. A great reduction in average number of Hofbauer cells in term placentas in our findings was close to that of Hofbauer (1925), Stieve (1941) and Hormann, who held the view that Hofbauer cells disappear from the placenta after the fourth month of pregnancy. Our observations were more in conformity with Roadway \& Marsh (1956) and Geller (1959), who showed that these cells were present in mature placenta but relative less in number.

Thus it was concluded that there was a significant increase in the placental weight, decidual area and umbilical cord diameter. There was also a significant increase in syncytial knot count, fibrinoid necrosis and vasculosyncytial membrane and decrease in the percentage of villi showing Cytotrophoblastic and Hofbauer cells in term group as compared to preterm group. All these changes are believed to facilitate the greater foetomaternal exchange as per need of foetus during late gestational age.

ZAIDI, M. T.; ARSHAD, M.; VASENWALA, S. M.; FARUQI, N. A.; KHAN, A. A. \& KHAN, S. Histomorfometría de placentas de pretérmino y término. Int. J. Morphol., 31(2):409-413, 2013.

La existencia intrauterina del feto depende de la placenta, el mayor órgano de nutrición y homeostasis. El estudio se llevó a cabo para comparar los cambios morfométricos e histológicos de la placenta humana de término y pretérmino. Ochenta placentas fueron obtenidas del Departamento de Obstetricia y Ginecología, JNMCH, AMU, Aligarh y se dividieron en grupos, el primer grupo de placentas de pretérmino hasta 36 semanas $(n=30)$ y el segundo grupo de placentas de término, de 37 a 40 semanas $(n=50)$. Las muestras fueron fijadas en solución de formol-salina al $10 \%$. Se estudiaron las variables morfológicas macroscópicas de las placentas. Hubo un aumento significativo en el peso de la placenta, el área de decidua y el diámetro del cordón umbilical de la placenta a término en comparación con la de los prematuros. De cada placenta se tomaron y se procesaron bloques de tejido para incluirlos en parafina. Cortes de $5 \mu \mathrm{m}$ fueron teñidos con HE y Van Gieson para microscopía óptica. De cada muestra fueron estudiadas 200 vellosidades, bajo campo de alta resolución y la aparición de diferentes características se expresó como porcentajes para cada parámetro. La aparición de las microvellosidades y brote sincitial en el sincitio estaban casi ausente en las vellosidades de las placentas de término. Se puede concluir que al aumentar la edad gestacional hubo un aumento gradual en el número de capilares en las vellosidades de la placenta de término. Existe un aumento significativo en el recuento de nudo sincitial, necrosis fibrinoide, membrana vasculosincisial y disminución en el porcentaje de las vellosidades que muestran células citotrofoblástica y número de células de Hofbauer en las placentas del término de grupo en comparación con el grupo de pretérmino.

PALABRAS CLAVE. Placenta; Nudo sincisial; Microvellosidades; Células de Hofbauer.

\section{REFERENCES}

Adair, F. L. \& Thelander, H. A study of the weight and dimensions of the human placenta in its relation to the weight of newborn infant. Is. J. Obst. \& Gynae, 10:17, 1925.

Clavero Nunez. op cit. in Histological abnormalities of the placentas. Pathology of the placenta. Fox H, Saunders 1978, 1962. p 156

Dow, P. \& Torpin, R Placentation studies: correlation between the size of the sac, area of the placenta, weight of the placenta and weight of the baby. Hum. Biol., 11:248, 1939.
Enders, A. C. \& King, B. F. The Cytology of Hofbauer cells. Anat. Rec., 167:231-52, 1970.

Fox, H. Abnormalities of the foetal stem arteries in the human placenta. J. Obs. \& Gynae. Br. Common, 74:734-8, 1967.

Fox, H. Pathology of placenta in maternal diabetes mellitus. Obs. and Gynae., 34:792-8, 1969.

Fox, H. \& Agrojojo, B. Foetoplacental function: its nature and assessment. The histopathology of placental insufficiency. $J$. 
clinical Pathol., 29 Suppl., 10:1-8, 1974.

Geller, M. F op cit. in Macroscopic abnormalities of the placentas: pathology of the placenta. Ed Fox H., Saunders 1978, 1959. p. 104.

Grannum and Hobbins.The placenta, USG in Obs \& Gynae. Ed Callen P.W, Saunders, 1983. p. 141.

Hofbauer, J. The function of Hofbauer cells of chorionic villi. Am. J. Obs. \& Gynae., 10:1, 1925.

Hormann, G. op cit in Histological abnormalities of the placenta: pathology of the placenta. Ed. Fox H. Saunders 1978. p. 157.

Jones, C. P. J. \& Fox, H. Syncytial knots and intervillous bridges in the human placenta: an ultrastructral study. J. Anat., 124:245, 1977.

Koslowski, H. M. The placenta USG diagnosis. In Obs \& Gynae. Springer-Verlag, 1980. p. 325.

Lyndon, M. \& Hill, M. D. Sonographic Assessment of the Umbilical Cord. Am. J. Obs. \& Gynae., 152:1229-30, 1987.

Mirchandani, J. S.; Mallik, G. B. \& Chitra, S. Villous fibrinoid necrosis and basement membrane thickening in toxaemia of pregnancy and its intrauterine growth retardation. J. Obs. \& Gynae., 29:1131, 1979.

Rodway, H. E. \& Marsh, F. A study of Hofbauer's cells in human placenta. J. Obs. \& Gynaec. Br. Empire., 63:111, 1956.

Schroder, R. op cit. in Histological Abnormalities of the placentas: pathology of the placenta,. Ed. Fox, H. Saunders 1978. p 156.

Stieve, H (1941).op cit. in Histological Abnormalities of the placentas: pathology of the placenta,. Ed. Fox, H. Saunders 1978. p 173.

Thompson, A. M.; Billewics, W. Z. \& Hytten, F. E. The weight of the placenta in relation to birthweight. J. Obs. \& Gynae. Br. Common., 76:865-72, 1969.

Tiwari, K.; Tyagi, S. P.; Saxena, K. F. \& Usmani, B. R. Ultrasonographic and histological studies of placenta in abnormal pregnanacy cases. J. Obs. \& Gynae. India, 47(2):11926, 1997.

Ursula, M. L. Ultra structure of the early human placenta. $B r . J$. Obs. \& Gynae., 71(1):21-32, 1964.

Younoszai, M. K. \& Howarth, J. C. Placental dimensions and relations in preterm, term and growth related infants. Am. $J$. Obs. \& Gynae., 103(2):265-71, 1969.

\author{
Address for correspondence \\ M. Tariq Zaidi \\ Department of Anatomy \\ JN Medical College \\ A.M.U. Aligarh 202002 \\ U.P. \\ INDIA
}

E-mail : mtzaidi@rediffmail.com

Received: 23-08-2011

Accepted: 12-09-2012 